\title{
Commentary: Locating Relict Sinter Terrace Sites at Lake Rotomahana, New Zealand, With Ferdinand von Hochstetter's Legacy Cartography, Historic Maps, and LIDAR
}

\author{
Rex Bunn* \\ Independent Researcher, Sydney, NSW, Australia \\ Keywords: Rotomahana, Hochstetter, forensic cartography, Tarawera, Pink Terrace, Tarata
}

\section{A Commentary on}

Locating Relict Sinter Terrace Sites at Lake Rotomahana, New Zealand, With Ferdinand von Hochstetter's Legacy Cartography, Historic Maps, and LIDAR

by Lorrey, A. M., and Woolley, J.-M. (2018). Front. Earth Sci. 6:205. doi: 10.3389/feart.2018.00205

\section{INTRODUCTION}

OPEN ACCESS

Edited by:

James D. L. White,

University of Otago, New Zealand

Reviewed by:

Jan Marie Lindsay,

The University of Auckland,

New Zealand

*Correspondence:

Rex Bunn

rexbunn2015@gmail.com

Specialty section:

This article was submitted to

Volcanology,

a section of the journal

Frontiers in Earth Science

Received: 03 December 2019

Accepted: 24 February 2020

Published: 11 March 2020

Citation:

Bunn R (2020) Commentary: Locating Relict Sinter Terrace Sites at Lake Rotomahana, New Zealand, With Ferdinand von Hochstetter's Legacy

Cartography, Historic Maps, and LIDAR. Front. Earth Sci. 8:68. doi: 10.3389/feart.2020.00068
This commentary addresses defects in research published in Lorrey and Woolley (2018a) and in the Frontiers of Earth Science article (Lorrey and Woolley, 2018b). This research professes to replicate the 2016-2018 reverse engineering (deconstructing survey bearings to resect the survey observation stations) of Ferdinand Hochstetter's 1859 survey of the Pink and White Terraces in New Zealand (Bunn and Nolden, 2016); These silica sinter terraces were a national treasure. They were known as the eighth "Wonder of the World." The Terraces attracted international tourists until 1886 when Mt Tarawera erupted, burying them. The replication presented in LW-2018a and LW-2018b draws mistaken conclusions after errata in data and in methodology. A competent survey resection is performed for this commentary, with the correct survey stations and baseline. The results are consistent with earlier reverse engineering of Hochstetter's survey. As lead investigator, I invited Lorrey and Woolley onto the 2017-2018 PAWTL2 Project team. The objective was to obtain evidence of surviving sinter terraces, by GPR (ground penetrating radar) searches over surveyed Pink, Black, and White Terrace locations. They do not acknowledge my invitation, their project participation, access to PAWTL2 staff or my research reports; which jointly underlay their attempt to replicate our 2016-2018 reverse engineering of Hochstetter's survey; in LW-2018a and LW2018b. Their GPR unit failed to penetrate to specified depths. Their attempted replication fails, after they experienced difficulties with interdisciplinary elements i.e., surveying, history, cartography, altimetry, and photo-interpretation (Bunn, 2019a,b). The cumulative errors in LW-2018a and LW$2018 \mathrm{~b}$ affect their resections and georeferencing, causing them to mislocate the Pink and White Terrace coordinates over today's lake This leads LW-2018b to erroneously conclude the terraces are destroyed.

\section{ERROR IN LOCATION OF PUAI ISLAND OBSERVATION STATION}

LW-2018b ignore the Puai Station western location (Bunn and Nolden, 2016, 2018; personal communications, Lorrey, 2017). They locate it on northeast Puai Island. Primary evidence for Puai Station is Bunn $(2019 a, b)$. This baseline error ruins their georeferencing. It nullifies their geothermal-feature coordinates in their Table S1. Analysis is then biased. 
Puai Station is further mislocated by LW-2018b choosing two-bearing resection from Kumete A and C. The $14^{\circ}$ included angle precludes establishing Puai Station with accuracy. Multibearing resection is required from three or more surviving landmarks. Their Puai Station error is pivotal. Given the $835 \mathrm{~m}$ survey baseline and distal Terrace locations, each meter of Puai error increases threefold when locating the White Terrace. This is sufficient for LW-2018b to mislocate the White Terrace location over today's lake, rather than on land. LW-2018b thereby join generations of geologists in assuming the Pink and White Terraces were destroyed. The unique primary evidence of Hochstetter's survey, when properly translated, deciphered, resected, and georeferenced, does not support this conclusion.

\section{ERRORS IN LANDMARKS AND BEARINGS}

Hochstetter recorded 29 Rotomahana bearings. Eleven distal landmarks survive. LW-2018b select five bearings from four surviving landmarks: three bearings from Station 21 and two from Puai Station. Two-bearing resection is inadequate. Their selection-bias delivers Type II errors (false negatives from their stringent landmark criteria). Distal landmarks $>25 \mathrm{~km}$ are excluded, precluding survey accuracy (which increases with distance). Bunn et al. (2018) found Hochstetter's bearings accurate to $\leq 100 \mathrm{~km}$ with $0.25^{\circ}$ mean error. Three landmarks lie on Kumete Ridge, where eruption surges passed, altering the landscape. Erosion followed, which is unmentioned. Forestry leaves Kumete Ridge periodically exposed. Here, Google Earth ${ }^{\mathrm{TM}}$ and site visits enable superior landmark identification to LIDAR.

Hochstetter provided for resecting his stations with rightangled bearing arrays from Kumete and Tarawera massif. The included angles from these arrays help confirm the landmarks (Bunn, 2019a,b). LW-2018b confine their Station 21 resection to Kumete $\mathrm{C}$ and $\mathrm{D}$ bearings, and their Puai resection to Kumete $\mathrm{A}$ and $\mathrm{C}$. They cannot so validate their landmarks. This further invalidates their georeferencing.

Five from six LW-2018b landmark bearings are mistaken:

Peak $\boldsymbol{A}$ by LW-2018b is on the plateau edge (Hochstetter recorded it as a peak on the track). This eroded position now is a forestry clearing and road (perhaps following the track). Peak $A$ is $\sim 70 \mathrm{~m} \mathrm{NNE}$ and $\sim+10 \mathrm{~m}$ elevation from LW-2018b; given roadforming and erosion. This error contributes to the LW-2018b $\sim 600 \mathrm{~m}$ error in Puai Station in Figure 1.

Peak $C$ was/is the highest point on Kumete Ridge with bearings from Station 21 and Puai. The LW-2018b assertion Peak C being co-located with Trig 543 is incorrect. There is no trig 543. Did they mean trig 3058 ? Trig stations did not exist here in 1859. It is unwise to assume today's landmarks were in Hochstetter's view.

Peak C location and bearing by LW-2018b from Puai is incorrect. They fail to consider Puai Station lay a meter above the lake, vs. Station 21 at $+30-40 \mathrm{~m}$ on a hilltop. Elevationprofiling shows Kumete $C$ (Trig 3058) and the LW-2018b location are unsighted due to the false summit. For Hochstetter to obtain the skyline, the Kumete-Puai summit bearing is taken $\sim 125 \mathrm{~m}$ in front of trig 3058, close to trig ALQC (Te Kumete). This LW-2018b error demonstrates the necessity for altimetry in such geospatial analysis.
Peak D bearing by LW-2018b is incorrect. Hochstetter's bearing was $334^{\circ} 20^{\prime}$ not $334.2^{\circ}$.

Makatiti bearing by LW-2018b appears reasonable: however Bunn et al. (2018) noted Makatiti skyline had two high-points.

Poroporo location and bearing by LW-2018b are incorrect. Poroporo location lies buried and despite PAWTL2 research, remains unidentified. The LW-2018b proxy bearing cannot be validated without excavation and thus cannot enter the analysis. As well, LW-2018b georeferenced the location of Poroporo on the flawed Petermann map, relying on their incorrect Puai location. The actual Poroporo location georeferenced from the correct Puai Station is $\sim 600 \mathrm{~m} \mathrm{~N}$ of LW-2018b.

\section{ERRORS IN RESECTION AND GEOREFERENCING}

LW-2018b use the same Hochstetter data and International Geomagnetic Reference Field declination of $+14.04^{\circ}$ as Bunn et al. (2018, p. 10) and Bunn (2019a,b). I tested the LW-2018b station resection using Google Earth ${ }^{\mathrm{TM}}$ in Figure 1. Their actual Station 21 proximity to our locus indicates the methodologies are consistent. This highlights LW-2018b mistakes at Puai.

Note: LW-2018a placed Station 21 on the southern shore of today's lake, with Pink Terrace $\sim 300$ m offshore, White Terrace onshore and the old lake $\sim 2,500 \mathrm{~m}$ long. The mean LW-2018a Terrace error is $\sim 345 \mathrm{~m}$ and the lake length error $\sim 900 \mathrm{~m}$.

Erroneous bearings confound LW-2018b georeferencing of August Petermann's map in LW-2018b Figure 12 (Hochstetter, 1864). I cannot replicate this, save by repeating their errata. When georeferencing Petermann's map over their stated (vs. actual) locations; we reproduce their smaller lake, displaced south and pivoting west (Hochstetter, 1864).

If we plot their actual locations, the Petermann map pivots $\sim 35^{\circ} \mathrm{E}$ and extends into the eastern lake, with Terraces in midlake (Hochstetter, 1864). To reconcile, I reprised their resection using their actual Station 21 coordinates, correct Puai Station and three-bearing resection from corrected landmarks and $\mathrm{Mt}$ Tarawera. The result is consistent with Bunn et al. (2018) and Bunn (2019a,b). The White Terrace location overlaps the shore with Pink Terrace location close onshore. How LW-2018b derived their stated loci remains opaque. This is crucial when evaluating their Hochstetter replication, for it is their stated loci which they claim replicates their colleagues' locations of the Pink and White Terraces (De Ronde et al., 2018).

\section{ERRORS IN CARTOGRAPHY}

LW-2018b assert that as more diary bearings appear to agree with Petermann's map locations than on Hochstetter's map then Petermann's map is superior. This is disingenuous for they knew from PAWTL2 reports that in 2017 I established Petermann's map is defective in 12 respects; after detecting the right-angled malrotation of Lake Rotomakariri (Hochstetter, 1867; Bunn, 2019a,b).

LW-2018b displayed diary bearings over either map and reported: all station 21 internal bearings...aligned [to Petermann] with consistent precision... and within the range of compass error. 


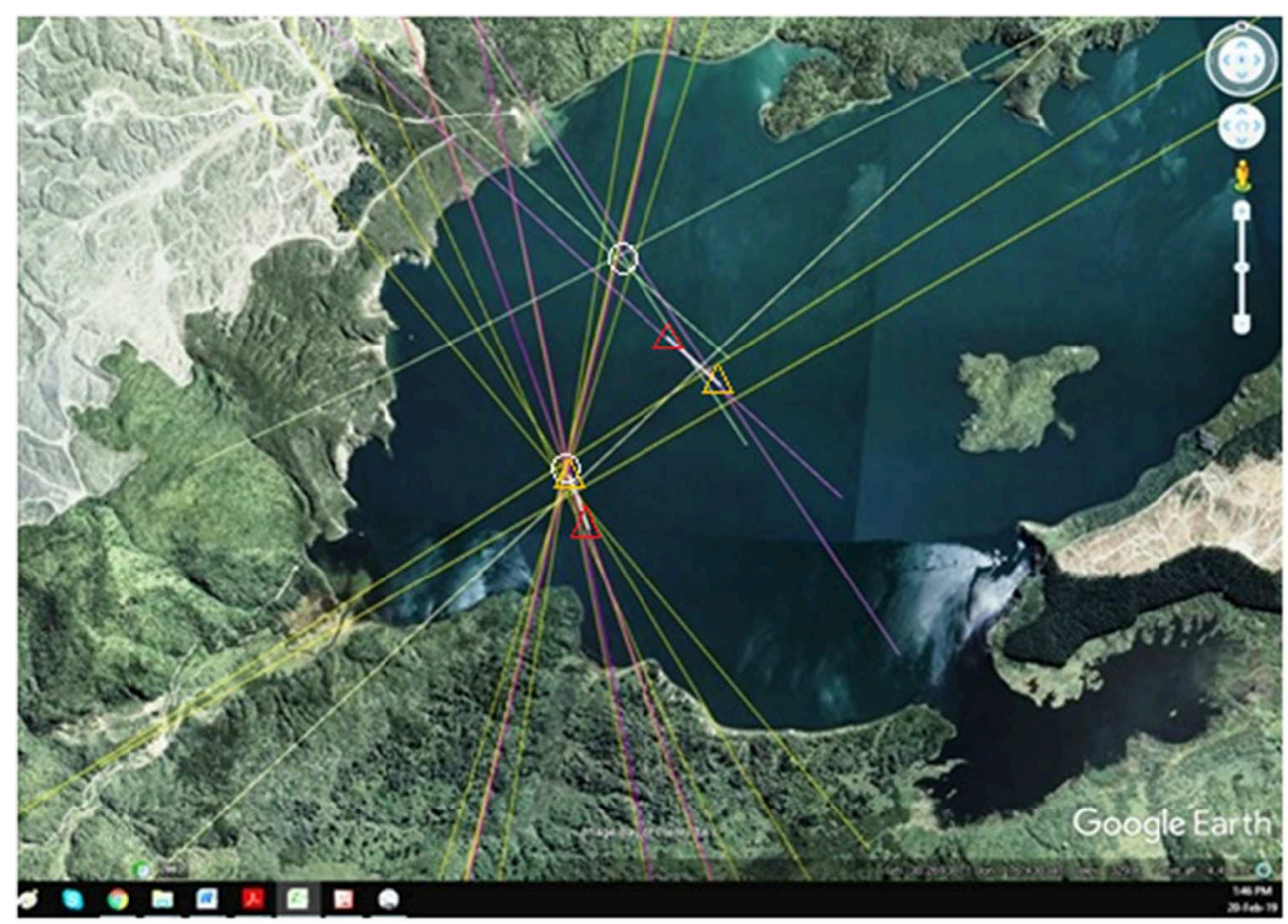

FIGURE 1 | Station 21 and Puai Station coordinates by LW-2018b, with Bunn 2018-2019b (Google Earth ${ }^{\text {TM}} /$ Bunn 2019 ). LW-2018b-3 purple rays resect Station 21. 2 light-purple rays resect Puai station. White rays measure gaps between actual and stated locations. Orange Triangles mark LW-2018b actual locations. Red triangles mark LW-2018b stated locations. Bunn-11 yellow rays resect Station 21. 3 green rays resect Puai Station. White circles mark (Bunn, 2019a,b) observation station coordinates. Note: LW-2018b actual Station 21 location is proximal to Bunn (2019a,b) locus, while their stated location is distal. Both LW-2018b stated and actual Puai coordinates are displaced southeast. Their actual error is $\sim 600 \mathrm{~m}$.

This is misleading, given varying sheet orientations: Petermann's lake axis lays $10^{\circ} \mathrm{E}$ against $23^{\circ} \mathrm{E}$ by Hochstetter. Resection and georeferencing are required before analysis of destroyed, proximal landmarks. Bunn (2019a,b) reported the Pink and White Terrace bearings were accurate on Hochstetter but not on Petermann. Georeferencing Hochstetter's map confirms the first proximal landmark, as predicted in Keam (2016). Petermann's does not. Rangipakaru Hill persists as Patiti Island, at credible altitude (Bunn, 2019a,b). LW-2018b mislocate Rangipakaru $\sim 500 \mathrm{~m} \mathrm{~W}$ of Patiti. Hochstetter's $295^{\circ}$ azimuth from Rangipakaru solfatara-Patiti, tracks the Black Terrace and Black Terrace Crater transects and search boxes in Bunn (2019a,b). Other proximal landmarks may now be empirically determined by triangulation and trilateration e.g., Poroporo.

In the LW-2018b Petermann Figure S8a, when I replicate to their exigent error of $\pm 0.5^{\circ}$, we note only $13 / 14$ proximal bearings. On plotting 14/14 bearings, 4/14 lie within error i.e., Tekapo, Pink Terrace, Whakaehu, and Kaiwaka. On Hochstetter: $5 / 14$ bearings fall within a conservative-realistic $\pm 1.0^{\circ}$ i.e., Pink and White Terraces, Puai, Pukura, and Kaiwaka (McFadgen, 1999). These are large features in Hochstetter's view. The others are hidden geothermal sites.

Petermann never visited New Zealand. In surveying, the field record is considered more accurate than later versions (personal communication Davies, 2018). The geothermal features were in bush and invisible. Hochstetter could take bearings via steam-plumes, with error due strong winds. This questions LW-2018b excluding surrogates, given precedent (Avery and Berlin, 1985).

Probably, Petermann drew his map favoring Hochstetter's diary bearings: delivering a deformed map. Their correspondence mentions survey errata (Hochstetter, 1860). Petermann exercised other creative license e.g., inventing Petermann land in 1868 (Tammiksaar et al., 1999).

\section{ERRORS IN ALTIMETRY}

Given old Lake Rotomahana vanished and the new lake, topography and elevations altered- researchers cannot establish old-lake feature coordinates without altimetry. The authors ignore the only published, evidence-based altimetry (Bunn and Nolden, 2018; Bunn et al., 2018; Bunn, 2019a,b).

\section{OTHER LW-2018B ERRORS}

- Station 21 and Puai Station lie today in the western not eastern arm of Lake Rotomahana.

- In their text and map scale bar, LW-2018b record one quarter of a nautical mile as $468 \mathrm{~m}$. It is $463 \mathrm{~m}$. 
- LW-2018b page 21 contains a straw-man fallacy i.e., that Bunn et al. (2018) relied on Admiralty declination data (rather than International Geomagnetic Reference Field (IGRF) model data). In Bunn and Nolden (2016), Bunn et al. (2018), and Bunn (2019a,b) we cited the IGRF correction. In 2017 (at PAWTL2 geologists' suggestion), I validated IGRF and Admiralty records, circulating the spreadsheet to PAWTL2 including Lorrey on $19 / 11 / 2017 \ldots$ nearly 12 months before LW-2018b was accepted for publication. In 2018, we published this validation, 4 months before $L W-2018 b$ was accepted viz.: the IGRF model gave the lowest average error, but the Admiralty data gave the smallest range. We elected the IGRF correction (Bunn et al., 2018, p. 10).

- LW-2018b use of coordinates to six decimal places is unsupported by Hochstetter.

- LW-2018b reiterate our Bunn et al. (2018) Mt Tarawera analysis without acknowledgment (p. 19). LW-2018b reject all Tarawera bearings from concern over eruption change, despite supporting evidence (Bunn and Nolden, 2018; Bunn et al., 2018).

- LW-2018b discard Hochstetter's right-angled bearings, which he provided for accuracy. This restricts them to two-variable resection, larger error ellipses and mislocated stations.

- LW-2018b echo (De Ronde et al., 2018), i.e., alleging our georeferencing distorts Hochstetter's maps. Bunn and Nolden (2018), Bunn et al. (2018), and Bunn (2019a,b) show no such aspect-ratio distortion. On Google Earth ${ }^{\mathrm{TM}}$ the Shift key maintains aspect-ratio.

\section{REFERENCES}

Avery, T. E., and Berlin, G. L. (1985). Interpretation of Aerial Photographs. Minneapolis, MN: Burgess, 25.

Bunn, A. R. (2019b). Hochstetter's survey of the Pink and White Terraces: the final iteration. Surv. Spatial 99, 30-35.

Bunn, A. R., Davies, N., and Stewart, D. (2018). Dr Hochstetter's Lost Survey. Surv. Spatial 94, 5-13.

Bunn, A. R., and Nolden, S. (2016). Te Tarata and Te Otukapuarangi: reverse engineering Hochstetter's Lake Rotomahana Survey to map the Pink and White Terrace locations. J. N. Zealand Stud. 23, 37-53. doi: 10.26686/jnzs. v0i23.3988

Bunn, A. R., and Nolden, S. (2018). Forensic cartography with Hochstetter's 1859 Pink and White Terraces survey: Te Otukapuarangi and Te Tarata. J. R. Soc. New Zealand 48, 39-56. doi: 10.1080/03036758.2017.13 29748

Bunn, R. (2019a). Photographic embellishment and fakery at the Pink and White Terraces. New Zealand Legacy 31, 5-10.

De Ronde, C. E. J., Tontini, F. C., and Keam, R. F. (2018). Where are the Pink and White Terraces of Lake Rotomahana?. J. R. Soc. New Zealand 48, 1-24. doi: 10.1080/03036758.2018.1474479

Hochstetter, F. (1860). Letter to August Petermann, Vienna, 1 November, Briefsammlung Ferdinand Hochstetter, Mappe 60, Sammlung Perthes, Schriftleitung Petermanns Geographische Mitteilungen, Forschungsbibliotek (Gotha).

Hochstetter, F. (1864). Published Map of Lake Rotomahana, 1864. Reprinted From Ferdinand Hochstetter and August Petermann, Geological and Topographical Atlas of New Zealand: Six Maps of the Provinces of Auckland and Nelson (Delattre).

Hochstetter, F. (1867). New Zealand. Stuttgart: Cotta, 419.

\section{DISCUSSION}

LW-2019a and LW-2018b is the first attempt to replicate our 2016-2019 Hochstetter survey research. Their replication fails due to their misplacing Puai Station, misidentifying landmarks, inadequate bearing sets, inaccurate bearings and reliance on Petermann's map (Hochstetter, 1864). The absence of altimetry restricts $\mathrm{LW}-2018 \mathrm{~b}$ to partial, $2 \mathrm{D}$ analysis. These factors contribute to their incorrect lake size and georeferencing. Their stated locations for Stations 21 and Puai could not be replicated. Their mean LW-2018b Terrace error is $\sim 430 \mathrm{~m}$. Correcting errata reveals agreement with Bunn et al. (2018) and Bunn (2019a,b). A competent replication of Hochstetter's survey is required, to validate Hochstetter's unique survey of this world wonder and to correct the scientific record. This will facilitate private and public sector research at Lake Rotomahana and provide closure for the Maori who grieve for relatives lost in the eruption.

\section{AUTHOR CONTRIBUTIONS}

The author confirms being the sole contributor of this work and has approved it for publication.

\section{ACKNOWLEDGMENTS}

I acknowledge Sascha Nolden's pivotal role in this 2015-2019 research. This is the sixth Pink and White Terraces article I have authored, each without taxpayer-funding.

Keam, R. F. (2016). The Tarawera eruption, Lake Rotomahana, and the origin of the Pink and White Terraces. J. Volcanol. Geotherm. Res. 314, 10-38. doi: 10.1016/j.jvolgeores.2015.11.009

Lorrey, A. M. (2017). Personal Communication With Rex Bunn.

Lorrey, A. M., and Woolley, J.-M. (2018a). "Location of the Pink, White and Black siliceous sinter Terraces at Lake Rotomahana, New Zealand: Re-evaluating Ferdinand von Hochstetter's legacy cartography and survey measurements with historic maps and LIDAR," in Lecture and Manuscript to Tuhourangi Tribal Authority and PAWTL2 Project Team (Rotorua). doi: 10.3389/feart.2018.00205

Lorrey, A. M., and Woolley, J.-M. (2018b). Locating Relic Sinter Terrace Sites at Lake Rotomahana, New Zealand With Ferdinand von Hochstetter's Legacy Cartography, Historic Maps and LIDAR. Front. Earth Sci. 6:205. doi: 10.3389/feart.2020.00068

McFadgen, B. (1999). "Surveying for Site Recording," in Archaeological Site Recording in New Zealand (Dunedin: New Zealand Archaeological Association), 93-104.

Tammiksaar, E., Sukhova, N. G., and Stone, I. R. (1999). Hypothesis versus fact: august petermann and polar research. Arctic 52, 237-244. doi: $10.14430 / \operatorname{arctic} 929$

Conflict of Interest: The author declares that the research was conducted in the absence of any commercial or financial relationships that could be construed as a potential conflict of interest.

Copyright (C) 2020 Bunn. This is an open-access article distributed under the terms of the Creative Commons Attribution License (CC BY). The use, distribution or reproduction in other forums is permitted, provided the original author(s) and the copyright owner(s) are credited and that the original publication in this journal is cited, in accordance with accepted academic practice. No use, distribution or reproduction is permitted which does not comply with these terms. 